\title{
Fast food consumption Drift in Pakistani population
}

\author{
Noor Jahan ${ }^{1}$, Mehjabeen ${ }^{2}$, Fakhsheena Anjum ${ }^{1,}$, , Sana Ghayas ${ }^{1}$, Hina Yasin ${ }^{1}$, M. Sajid ${ }^{1}$, \\ S. M. Zubair Qasmi ${ }^{1}$, Umair Akhtar ${ }^{1}$, Umar Akram ${ }^{1}$, Haider Raza ${ }^{1}$, Ahmed Ali ${ }^{1}$, Talha Rana ${ }^{1}$ \\ ${ }^{1}$ Dow College of Pharmacy, Dow University of Health Sciences, Karachi, Pakistan \\ ${ }^{2}$ Faculty of Pharmacy, Federal Urdu University of Arts, Science and Technology, Karachi, Pakistan
}

\section{Email address:}

fakhsheena.anjum@duhs.edu.pk (F. Anjum)

\section{To cite this article:}

Noor Jahan, Mehjabeen, Fakhsheena Anjum, Sana Ghayas, Hina Yasin, M. Sajid, S. M. Zubair Qasmi, Umair Akhtar, Umar Akram, Haider Raza, Ahmed Ali, Talha Rana. Fast Food Consumption Drift in Pakistani Population. Journal of Food and Nutrition Sciences. Vol. 2, No. 1, 2014, pp. 13-18. doi: 10.11648/j.jfns.20140201.12

\begin{abstract}
Objective: To appraise the use of various fast foods in different age groups among males and females and study its drift in Pakistani population. Method: The study was conducted from February to June 2013 in Karachi, Pakistan on a structured questionnaire. A total of $n=489$ individuals participated in this study among which $n=222$ were males and $\mathrm{n}=267$ were females whose ages were grouped as $<18$ years, $18-40$ years and $>40$ years. Fast food was categorized as fries, burgers, rolls, chicken broast and pizza whereas fibrous and vegetable diet included all vegetables in this study. Different types of diseases i.e. diabetes, asthma, hypertension, allergy, GI disorders and skin infections were also enquired about from the respondents consuming fast food. Result: The diet comprising fast food is high in energy and energy density. Fast food consumption has been reported to go along with large amounts of soft drinks which not only augments the weight of the individuals but also put them at danger to different kinds of ailments. In our study, both the genders were reported to take fast food on weekly basis, highest consumed in the age group of 18-40 years. Most popular fast food consumed among the females $(n=63)$ was fries + burger and that in males $(n=69)$ was more than one type of fast food. The consumption of cold drinks with fast food was seen more in males $(n=105)$ than in females $(n=90)$ and mostly in the age group of $18-40$ years (males $n=72$ and females $n=45$ ). The consumption of fast food more than one time was observed more in the males. Both the genders belonged to age group of 18-40 years who exercised regularly. The frequency of use of fibrous/vegetable diet was higher in females $(n=90)$ as compared to the male gender $(n=117)$ in the age group of $18-40$ years $\left(p=0.033, \chi^{2}=\right.$ 8.706). It was observed that the increase in weight was more in females under 18 years of age and more in males of age 1840 years. It was also found that overall $(n=72)$ males and $(n=81)$ females were suffering from various diseases and yet were consuming fast food. Conclusion: Frequent fast food consumption may contribute to weight gain and with a sedentary life style can put the individuals at stake of different kinds of diseases and high health burden. Knowledge regarding healthy diet and healthy life style can contribute towards a society of people with better productivity and economy.
\end{abstract}

Keywords: Fast Food, Beverages, Obesity, Energy

\section{Introduction}

The Americans work for added hours and do even more than one job nowadays than years ago. The married couples are working even longer as seen over the past three decades. Women are working more today than in the past, especially single mothers [1]. Due to these circumstances, people have very less time for preparing their food at their homes and they prefer to have it away from home. It was reported in 1993 that about 38 percent of total food expenditure dollars were used up on food away from home which augmented to 42 percent as in reports of 2001 [2].
It was observed that due to increased frequency of food intake in fast food restaurants, women had higher energy and fats intake and hence this resulted in greater body weight [3]. Eating out frequently is associated with increased intake of energy [4]. The energy intake of the Americans has amplified over the past 2 decades and this has been observed athwart age groups [5]. Food and beverages that are provided in fast food places regularly come in large share volume which also contributes to increase in weight of the people [6].

Nowadays, it is seen that the stratum of physical activity has reduced increasing the prevalence of obesity and vital changes in the diet of individuals have come about. Some 
of these changes are due to the consumption of food from restaurant and fast-food places. Today, a common American devour much of the energy at restaurants and fast-food places especially the young adults (aged 19 to 39) who take close to $30 \%$ of their energy from such places whereas older individuals and the elderly devour much less. More reports on greater food utilization in restaurants and fastfood establishments are also seen [7].

Fast food restaurants frequently aim younger generation with television and Internet advertising. Childhood corpulence and other disorders like diabetes may be linked to the haughty fat and sodium content of such fast foods. The majority of nutritionists and numerous authors sensed that the youth was eating more fast-foods outside the home than their elders [8]. The fast food industry at first progressed in the 1940s in California which altered the consumption practice of numerous countries globally including Asian countries [9]. Fast food consumption has increased drastically in Pakistan due to different aspects such as attraction for eating out, socialization, urbanization, etc. People like eating out in modern ways due to globalization that has affected the preparation and presentation of fast food. Urbanization also amends standard of living and it had been affirmed that food requisite is related to it. It was found that the Western style food consumption augmented in the developing countries as the income position of the people improved [10].

Wood studied in Houston that merely 3\% of children's meals accessible at a series of fast food restaurants met dietary values as described by the National School Lunch Program [11]. Research also indicated that those who ate fast food at home and also those students who attended school close to fast food restaurants were more probable to be overweight [12]. Some other researchers also tried to find such links and the rates of heavy students in California [13]. In Turkey, about one-third of the research participants chose fast food as snack for once or more times daily while only $15 \%$ consumed the recommended daily amount of fruits and vegetables [14]. Goyal and Singh (2007) revealed in their research that Indian young consumers had ardor to visit fast food places for enjoyment but home food was their first preference [15]. People feel contentment in having fast food daily, although it is detrimental to their health. Cancer is also a cause of fast food consumption and it can be $25 \%$ due to high fat and fried food [16].

Policy makers in many cities have countered by restraining the ease of access or content of fast food, or by requiring posting of the caloric content of the meals [17]. Jekanowski, Binkley, and Eales (2001) also did studies to evaluate the upshot of cost, earnings, and demographic distinctiveness on fast food [18]. Ekelund and Watson (1991), too, found that fast food utilization was empirically related to opportunity expenditure of the household [19].

\section{Methodology}

The study was conducted from February to June 2013 in
Karachi, Pakistan on a structured questionnaire developed by the researchers from different published sources. A total of $n=489$ individuals participated in this study among which $n=222(45 \%)$ were males and $n=267(55 \%)$ were females. Ages of $<18$ years, $18-40$ years and $>40$ years were grouped in both the genders so as to have appropriate calculations regarding various questions. Fries, burgers, rolls, chicken broast and pizza were categorized as fast food in this study. Fibrous and vegetable diet included all vegetables especially spinach, lady finger and all types of fruits in this study. Different types of diseases were also enquired in the questionnaire which included diabetes, asthma, hypertension, allergy, GI disorders and skin infections despite of having which people consumed fast food on regular basis. The data was analyzed statistically using SPSS version 19.0

\section{Results and Discussions}

Fast food establishments are well-liked places for food consumption than homes. Fast food is swift, handy, and somewhat economical for the quantity of food attained, and is striking to all age groups [2, 3, 6, 20]. Fast food establishments have increased much and public is also consuming food at such places more than many years ago $[2,3,6,21,22]$. As shown in Table 1, majority of the males consumed fast food on monthly $(n=24,11 \%)$ and weekly $(n=138,62 \%)$ basis, highest consumed in the age group of 18-40 years on weekly basis. In females, highest fast food consumption was recorded on weekly $(n=135,50.5 \%)$ and then on monthly $(n=96,36 \%)$ basis, again highest consumed in the age group of $18-40$ years.

Table 1. Frequency of fast food intake in various age groups

\begin{tabular}{ccccc}
\hline Gender & Age & \multicolumn{3}{c}{ Frequency of fast food intake } \\
\hline \multirow{3}{*}{ Male } & & Daily & Weekly & Monthly \\
& Under 18 & 18 & 42 & 06 \\
& 18-40 Years & 39 & 84 & 03 \\
\multirow{3}{*}{ Total } & 40 Above & 03 & 12 & 15 \\
& & 60 & 138 & 24 \\
Female & Under 18 & 24 & 54 & 36 \\
& 18-40 Years & 12 & 78 & 39 \\
Total & 40 Above & 00 & 03 & 21 \\
\hline
\end{tabular}

The male respondents of all ages consumed particularly more than one type of fast food (Table 2). The types of food intake emulate the move in utilization from at home to away from home [23, 24]. Such food includes enlarged intakes of salty refreshments, soft drinks, and pizza [25, 26]. The female respondents of various age groups showed difference in their food choice in which fries were consumed at a trendy level (Table 2). It was seen in 1996 that all of the consumed burgers and $50 \%$ or more of the fries eaten by all age groups were consumed in restaurant or fast-food places. Therefore, it revealed that easily obtainable items are prepared at home only by a very few 
individuals $[27,28]$. Table 2 reveals that the frequency of consuming various fast foods declined with age in both the genders esp. at the age $>40$ years. Various other researchers have stated that some age groups, (19 to 39 years), consume approximately $30 \%$ of their vigor from restaurant and fast-food places but older age groups consume much less [7].

Table 2. Types of fast food consumed by various age groups

\begin{tabular}{|c|c|c|c|c|c|c|c|c|c|c|}
\hline Gender & Age & & & & & Types of fas & od & & & Total \\
\hline \multirow{4}{*}{ Male } & & $\begin{array}{c}\text { Fries } \\
\text { (A) }\end{array}$ & $\begin{array}{l}\text { Burger } \\
\text { (B) }\end{array}$ & $\begin{array}{l}\text { Roll } \\
\text { (C) }\end{array}$ & $\begin{array}{l}\text { Broast } \\
\text { (D) }\end{array}$ & $\begin{array}{l}\text { More Than } \\
\text { One (A-D) }\end{array}$ & Pizza & $\begin{array}{l}\text { Fries }+ \text { Burger } \\
\text { (combination) }\end{array}$ & $\begin{array}{c}\text { Fries + Burger } \\
+ \text { Pizza } \\
\text { (combination) }\end{array}$ & \\
\hline & Under 18 & 18 & 6 & 00 & 03 & 21 & 0 & 15 & 03 & 66 \\
\hline & $18-40$ Years & 03 & 36 & 00 & 06 & 33 & 6 & 21 & 21 & 126 \\
\hline & 40 Above & 00 & 03 & 03 & 06 & 15 & 0 & 00 & 03 & 30 \\
\hline \multirow[t]{2}{*}{ Total } & & 21 & 45 & 03 & 15 & 69 & 6 & 36 & 27 & 222 \\
\hline & Under 18 & 24 & 6 & 03 & 03 & 15 & 0 & 39 & 24 & 114 \\
\hline \multirow[t]{2}{*}{ Female } & $18-40$ Years & 21 & 30 & 03 & 03 & 36 & 3 & 21 & 12 & 129 \\
\hline & 40 Above & 00 & 06 & 00 & 03 & 06 & 3 & 03 & 03 & 24 \\
\hline Total & & 45 & 42 & 06 & 09 & 57 & 6 & 63 & 39 & 267 \\
\hline
\end{tabular}

Table 3. Frequency of taking fast food by different age groups

\begin{tabular}{llccccc}
\hline Gender & Age & \multicolumn{4}{c}{ Time of Taking Fast Food } & Total \\
\hline \multirow{4}{*}{ Male } & Under 18 & 21 & 33 & 09 & 03 & 66 \\
& 18-40 Years & 27 & 27 & 36 & 36 & 126 \\
& 40 Above & 03 & 06 & 15 & 06 & 30 \\
Total & & 51 & 66 & 60 & 45 & 222 \\
& & & Evening & Dinner & $\begin{array}{c}\text { More Than } \\
\text { One Time }\end{array}$ \\
Female & 18-40 Years & 30 & 78 & 06 & 12 & 126 \\
& 40 Above & 00 & 12 & 12 & 00 & 24 \\
Total & & 39 & 171 & 27 & 27 & 264 \\
\hline
\end{tabular}

Table 4. Use of cold drink with fast food by various age groups

\begin{tabular}{llccc}
\hline Gender & Age & \multicolumn{3}{c}{ Use of Cold Drink With Fast Food } \\
\hline \multirow{3}{*}{ Male } & & Yes & No & Total \\
& Under 18 & 27 & 36 & 03 \\
& 18-40 Years & 72 & 48 & 06 \\
Total & 40 Above & 06 & 21 & 00 \\
& & 105 & 105 & 09 \\
\multirow{3}{*}{ Female } & Under 18 & 42 & 63 & 09 \\
& 18-40 Years & 45 & 66 & 18 \\
Total & 40 Above & 03 & 09 & 09 \\
\hline
\end{tabular}

As seen from the Table 3, males of age 18-40 years mainly took fast food as dinner $(n=3,28.6 \%)$ whereas females under 18 years and 18-40 years of age had fast food in the evening $(n=81,71 \%$ and $n=78,60 \%$ respectively). The consumption of fast food more than one time was observed more in the males than in the females $\left(p=0.012, \chi^{2}=18.031\right)$. Consumption of cold drinks with fast food (Table 4) was seen more in males $(n=105,47 \%)$ than in females $(n=90,34 \%)\left(p=<0.001, \chi^{2}=17.797\right)$ and in both the genders, the highest consumption was observed in the age group of $18-40$ years (males $n=72,57 \%$ and females $\mathrm{n}=45,35 \%)$. More males $(\mathrm{n}=96,43.2 \%)$ did regular exercise than the females $(n=72,27.3 \%)$ on regular basis $\left(p<0.001, \chi^{2}=14.476\right)$ as shown in Table 5. Both the genders belonged to age group of 18-40 years. The frequency of use of fibrous diet was higher in females overall as compared to the male gender $\left(\mathrm{p}=0.033, \chi^{2}=8.706\right)$ i.e. $\mathrm{n}=237(89 \%)$ and $\mathrm{n}=174(78 \%)$ respectively (Table 6$)$. In both the genders, age group of 18-40 years used fibrous diet the most $(n=90$, $71 \%$ males and $n=117,91 \%$ females).

Table 5. Regular exercise in males and females

\begin{tabular}{lllcc}
\hline Gender & Age & \multicolumn{2}{c}{ Regular Exercise } & Total \\
\hline \multirow{4}{*}{ Male } & & Yes & No & \\
& Under 18 & 27 & 39 & 66 \\
& 18-40 Years & 60 & 66 & 126 \\
Total & 40 Above & 09 & 18 & 27 \\
& & 96 & 123 & 219 \\
Female & Under 18 & 21 & 93 & 114 \\
& 18-40 Years & 45 & 81 & 126 \\
Total & 40 Above & 06 & 18 & 24 \\
\hline
\end{tabular}

Table 6. Use of fruits/vegetables in diet by various age groups

\begin{tabular}{llccccc}
\hline Gender & Age & \multicolumn{4}{c}{ Use Of Fruits/Vegetables } & Total \\
\hline \multirow{4}{*}{ Male } & Under 18 & 03 & 12 & 0 & 42 & 57 \\
& 18-40 Years & 12 & 00 & 6 & 72 & 90 \\
& 40 Above & 00 & 06 & 0 & 21 & 27 \\
Total & & 15 & 18 & 6 & 135 & 174 \\
& Under 18 & 06 & 06 & 0 & 87 & 99 \\
Female & 18-40 Years & 09 & 03 & 6 & 99 & 117 \\
& 40 Above & 00 & 00 & 0 & 21 & 21 \\
Total & & 15 & 09 & 6 & 207 & 237 \\
\hline
\end{tabular}

Increase in weight due to fast food consumption (Table 7) was observed more in females $<18$ years of age and more in males of age group 18-40 years. Slight difference in the increase in weight was observed in both the genders in age 
group $>40$ years. It had been reported that intake of food outside the home mounted, adding to enlarged energy intake and also increasing obesity among individuals [29]. Enlarged energy intake could be ascribed to the consumption of large fraction volume of foods and beverages $[30,31]$.

Table 7. Weight increase in various age groups

\begin{tabular}{llccc}
\hline Gender & Age & \multicolumn{2}{c}{ Weight Increase } & Total \\
\hline \multirow{4}{*}{ Male } & & Yes & No & \\
& Under 18 & 21 & 45 & 66 \\
& 18-40 Years & 78 & 48 & 126 \\
Total & 40 Above & 18 & 12 & 30 \\
& & 117 & 105 & 222 \\
Female & Under 18 & 51 & 60 & 111 \\
& 18-40 Years & 54 & 75 & 129 \\
Total & 40 Above & 12 & 12 & 24 \\
\hline
\end{tabular}

The overall diet of all individuals must be focused due to the prevalence of obesity coupled with co-morbidities [32, $33,34]$. From Table 8 , it can be seen that out of 222 males, $\mathrm{n}=72(32.4 \%)$ were suffering from various diseases and out of 264 females, $n=81(30.7 \%)$ had different diseases; in both the genders, GIT diseases were the most common i.e. $\mathrm{n}=24,10.1 \%$ in males and $\mathrm{n}=27,10.2 \%$ in females. Various researches revealed that fast food was high in energy density and provided 158 to 163 kilocalories per 100 grams of food consumed. The diet of fast food eaters was poorer in vitamin $\mathrm{A}$, carotenes, and vitamin $\mathrm{C}$ density which are good sources for the promotion of good health and for the prevention of cancer also [35-39]. Fast food was also linked to consumption of a diet squat in calcium and magnesium density which are related with bone health of individuals [40-44]. In the U.S., 30.5 percent adults are obese and obesity endangers individuals to various ailments like stroke, hypertension, diabetes, etc [45-47].

Table 8. Diseases existing in various age groups consuming fast food

\begin{tabular}{|c|c|c|c|c|c|c|c|c|c|c|}
\hline \multirow[t]{2}{*}{ Gender } & \multirow[t]{2}{*}{ Age } & \multicolumn{9}{|c|}{ Kind Of Diseases } \\
\hline & & CVD & $\mathrm{DM}$ & HTN & Allergy & Skin Infection & GIT & Respiratory & Other & Total \\
\hline \multirow{3}{*}{ Male } & Under 18 & 0 & 0 & 00 & 03 & 03 & 06 & 0 & 00 & 12 \\
\hline & $18-40$ Years & 0 & 3 & 03 & 06 & 09 & 18 & 0 & 00 & 39 \\
\hline & 40 Above & 3 & 0 & 09 & 00 & 00 & 00 & 6 & 03 & 21 \\
\hline \multirow[t]{2}{*}{ Total } & & 3 & 3 & 12 & 09 & 12 & 24 & 6 & 03 & 72 \\
\hline & Under 18 & 0 & 0 & 00 & 09 & 06 & 03 & 0 & 12 & 30 \\
\hline \multirow[t]{2}{*}{ Female } & 18-40 Years & 0 & 3 & 03 & 06 & 00 & 21 & 3 & 03 & 39 \\
\hline & 40 Above & 0 & 3 & 06 & 00 & 00 & 03 & 0 & 00 & 12 \\
\hline Total & & 0 & 6 & 09 & 15 & 06 & 27 & 3 & 15 & 81 \\
\hline
\end{tabular}

It is important for public that they should be aware of the nutritional aspects of the food they consume at restaurants and fast food places. One significant approach of shifting the diet of people is to persuade them to eat at home more and make better selection at restaurants and fast food establishments. The consumers should be encouraged to eat more fruits and vegetables and smaller amounts of high-fat mixed-grain-based food. Through these interventions, the mount in obesity will be restricted along with the comorbidities in the people, hence producing healthy communities worldwide [48].

\section{Conclusion}

Fast food is convenient and tasty though prepared with low nourishing or unhealthy ingredients. Fast food companies are targeting youngsters through great promotion strategies, delicious recipes and attractive advertisement. There are much greater side effects of fast food and people are unaware of its ill consequences which can tend to many detrimental diseases; extended use of fast food is also a cause of health problems and obesity. Working class prefers fast food at their workplace due to their busy schedules and they also compromise with the food quality due to shortage of time and ease of access. Moreover, fast food is also an addiction for most of the people. It is recommended that parents should keep an eye on the diet of their children as youngsters spend more money on junk food and must have balanced diet for proper growth. Moreover, policy makers should limit or ban the unhealthy fast food restaurants that are using cheap quality ingredients for food preparation; media should also spread awareness among people about the side effects of taking fast food frequently.

\section{References}

[1] U.S. Department of Labor, Bureau of Labor Statistics: Working in the 21st Century (Chartbook): Married Couples Are Working Longer. Available at: http://www.bls.gov/opub/working/page17b.

[2] U.S. Department of Labor, Bureau of Labor Statistics: Average Annual Expenditures and Characteristics of All Consumer Units, Consumer Expenditure Survey, 1993-2001. Available http://www.bls.gov/cex/2001/standard/multiyr.pdf. 
[3] French SA, Harnack L, Jeffery RW. Fast food restaurant use among women in Pound of Prevention study: dietary, behavioral and demographic correlates. J Obes Relat Metab Disord 2000; 24:1353- 1359.

[4] Eke-Clemens LH, Slawson DL, Klesges RC. The effect of eating out on quality of diet in premenopausal women. J Am Diet Assoc 1999; 99:442- 444.

[5] Nielsen SJ, Siega-Riz AM, Popkin BM. Trends in energy intake in U.S. between 1977 and 1996. Similar shifts seen across age groups. Obes Res 2002; 10:370-378.

[6] DeMaria AN. Editor's Page (Of fast food and franchises). J Am Coll Cardiol 2003; 41:1227- 1228.

[7] Clemens LH, Slawson DL, Klesges RC. The effect of eating out on quality of diet in premenopausal women. J Am Diet Assoc 1999; 99:442-444.

[8] Bigler-Doughten, S, Jenkins RM. Adolescent snacks: Nutrient density and nutritional contribution to total intake. J Am Diet Assoc 1987; 87:1678-1679.

[9] Schlosser E. Fast Food Nation 2001. New York, NY: Houghton Mifflin.

[10] Regmi A, Dyck J. Effects of Urbanization on Global Food Demand. USDA FAS 2001; WRS-01-1.

[11] Wood M. Kids, Fast Food \& Obesity. Agricultural Research 2009; 57(9):20-21.

[12] Davis B, Carpenter C. Proximity of Fast-Food Restaurants to Schools and Adolescent Obesity. American Journal of Public Health 2009; 99(3):505-510.

[13] Howard PH, Fitzpatrick M, Fulfrost B. Proximity of food retailers and rates of overweight ninth grade students: an ecological study in California. BMC Public Health 2011; 11(1):68-75.

[14] Akman M, Akan H, Izbirak G, Tanriover O, Tilev S, Yildiz A, Hayran O. Eating patterns of Turkish adolescents. A cross-sectional survey. Nutrition Journal 2010; 9:67.

[15] Goyal A, Singh NP. Consumer perception about fast food in India. An exploratory study. British Food Journal 2007; 109(2):182-195.

[16] Watson R, Mufti I. Nutrition and Cancer Prevention. Florida 1995; CRC Press.

[17] Mair J, Pierce M, Stephen T. The Use of Zoning to Restrict Fast Food Outlets. A Potential Strategy to Combat Obesity. The Center for Law and the Public's Health at Johns Hopkins and Georgetown Universities 2005.

[18] Jekanowski MD, Binkley JK, Eales J. Convenience, Accessibility, and the Demand for Fast Food. Journal of Agricultural and Resource Economics 2001; 26(1):58-74.

[19] Ekelund RBJr, Watson JK. Restaurant Cuisine, Fast Food and Ethnic Edibles. An Empirical Note on Household Meal Production. Kyklos 1991; 44(4):613-27.

[20] French SA: Pricing affects food choices. J Nutr 2003; 133:841-843.

[21] Guthrie JF, Lin B-H, Frazao E. Role of food prepared away from home in the American diet, 1977-78 versus 1994-96: changes and consequences. J Nutr Educ Behav 2002;
$34: 140-150$.

[22] French SA, Story M, Neumark-Sztainer D, Fulkerson JA, Hannan P. Fast food restaurant use among adolescents: associations with nutrient intake, food choices, and behavioral and psychosocial variables. In $\mathrm{J}$ Obes Relat Metab Disord 2001; 25:1823- 1833.

[23] Jahns L, Siega-Riz AM, Popkin BM. The increasing prevalence of snacking among U.S. children from 1977 to 1996. J Pediatr 2001; 138:493-498.

[24] Zizza C, Siega-Riz AM, Popkin BM. Significant increase in young adults' snacking between 1977-1978 and 1994-1996 represents a cause for concern. Prev Med 2001; 32:303-310.

[25] Harnack L, Stang J, Story M. Soft drink consumption among U.S. children and adolescents. Nutritional consequences. J Am Diet Assoc 1999; 99:436-441.

[26] Cavadini C, Siega-Riz AM, Popkin BM. U.S. adolescent food intake trends from 1965 to 1996. Arch Dis Child $2000 ; 83: 18-24$.

[27] Popkin BM, Haines PS, Reidy KC. Food consumption trends of U.S. women. Patterns and determinants between 1977 and 1985. Am J Clin Nutr 1989; 49:1307-1319.

[28] Popkin BM, Siega-Riz, AM, Haines PS. A comparison of dietary trends among racial and socioeconomic groups in the United States. N Engl J Med 1996; 335:716-720.

[29] Binkley JK, Eales J, Jekanowski M. The relation between dietary change and rising U. S. obesity. Int J Obes Relat Metab Disord 2000; 24:1032-1039.

[30] Matthissen J, Fagt S, Biltoft-Jensen A, Beck AM, Ovesen L. Size makes a difference. Public Health Nutr 2003; $6: 65-72$

[31] Young RL, Nestle M. Expanding portion sizes in the U.S. marketplace. Implications for nutrition counseling. J Am Diet Assoc 2003; 103:231- 234.

[32] Flegal KM, Carroll MD, Kuczmarski RJ, Johnson CL. Overweight and obesity in the United States. Prevalence and trends, 1960-1994. Int J Obes Relat Metab Disord $1998 ; 22: 39-47$.

[33] Troiano RP, Flegal KM, Kuczmarski RJ, Campbell SM, Johnson CL. Overweight prevalence and trends for children and adolescents. The National Health and Nutrition Examination Surveys, 1963 to 1991. Arch Pediatr Adolesc Med 1995; 149:1085-1091.

[34] Allison DB, Fontaine KR, Manson JE, Stevens J, VanItallie TB. Annual deaths attributable to obesity in the United States. JAMA 1999; 282:1530-1538.

[35] Brown DJ, Goodman J. A review of vitamins A, C, and E and their relationship to cardiovascular disease. Clin Excell Nurse Pract 1998; 2:10- 22.

[36] Ford ES, Mokdad AH. Fruit and vegetable consumption and diabetes mellitus incidence among U.S. adults. Prev Med. $2001 ; 32: 33-39$.

[37] Institute of Medicine (US), Food and Nutrition Board: Dietary Reference Intakes for Vitamin C, Vitamin E, Selenium, and Carotenoid. Washington, DC: National Academy Press, 2000. 
[38] Joshipura KJ, Hu FB, Manson JE, Stampfer MJ, Rimm EB, Speizer FE, Colditz G, Ascherio A, Rosner B, Spiegelman D, Willett WC. The effect of fruit and vegetable intake on risk for coronary heart disease. Ann Intern Med 2001; 134:11061114.

[39] McDermott JH. Antioxidant nutrients. Current dietary recommendations and research update. J Am Pharm Assoc 2000; 40:785- 799 .

[40] Illich JZ, Brownbill RA, Tamborini L. Bone and nutrition in elderly women: protein, energy, and calcium as main determinants of bone mineral density. Eur J Clin Nutr 2003; $57: 554-565$

[41] Moyad MA. Osteoporosis. Part III-Not just for bone loss. Potential benefits of calcium and vitamin D for overall general health. Urol Nurs 2003; 23:69- 74 .

[42] New SA, Millward DJ. Calcium, protein, and fruits and vegetables as dietary determinants of bone health. Am J Clin Nutr 2003; 77:1340-1341.

[43] New SA, Robins SP, Campbell MK, Martin JC, Garten MJ, Bolten-Smith C, Grubb DA, Lee SJ, Reid DM. Dietary influences on bone mass and bone metabolism: further evidence of a positive link between fruit and vegetable consumption and bone health. Am J Clin Nutr 2000; $71: 142-151$.

[44] Tucker KL, Hannan MT, Chen H, Cupples LA, Wilson PW, Kiel DP. Potassium, magnesium, and fruits and vegetable intakes are associated with greater bone mineral density in elderly men and women. Am J Clin Nutr 1999; 69:727- 736

[45] Braig GA: The underlying basis for obesity. Relationship to cancer. J Nutr 2002; 132:3451-3455.

[46] Calle EE, Rodriguez C, Walker-Thurmod K, Thun MJ. Overweight, obesity, and mortality from cancer in a prospective studied cohort of U.S. adults. N Engl J Med 2003; 348:1625- 1638.

[47] Paeratakul S, Lovejoy JC, Ryan DH, Bray GA. The relation of gender, race, and socioeconomic status to obesity and obesity comorbidities in a sample of U.S. adults. Int J Obes Relat metab Disord 2002; 26:1205- 1210.

[48] Stockmyer C. Remember when mom wanted you home for dinner. Nutr Rev 2001; 59:57-60. 